\title{
Chemically Modified Heparin Inhibits Mesangial Cell Proliferation Induced by High Glucose through Interfering with the Cell Cycle
}

\author{
Deng-Ke YIN, ${ }^{a, b}$ Wen-Bing YAO, ${ }^{a}$ and Xiang-Dong GAO ${ }^{*, a}$ \\ ${ }^{a}$ School of Life Science and Technology, China Pharmaceutical University; 24 Tongjia Road, Nanjing City 210009, China: \\ and ${ }^{b}$ School of Pharmacy, Anhui College of Traditional Chinese Medicine; 45 Shihe Road, Hefei City 230038, China. \\ Received May 27, 2007; accepted September 7, 2007
}

The aims of this study were to investigate whether chemically modified non-anticoagulation heparin derivate (Periodate-Oxidized/Borohydride-Reduced modified heparin (OR-heparin)) can inhibit high glucose-induced human mesangial cell proliferation and its influence on the cell cycle. OR-heparin with low anticoagulation activity inhibited high glucose-induced early proliferation in a dose-dependent manner. OR-heparin released high glucose-arrested mesangial cells at $G_{1}$ phase, and dose-dependently increased $S$ phase. OR-heparin also inhibited

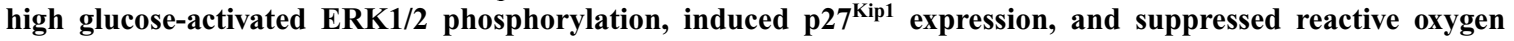
species (ROS) accumulation in a dose-dependent manner. Our results suggest that OR-heparin releases high glucose-arrested cells on $G_{1}$ phase and inhibits high glucose-induced mesangial cell proliferation through blocking ERK1/2 phosphorylation and delaying $S$ phase progression, which may be in correlation with $O R$-heparin suppressing ROS accumulation.

Key words periodate-oxidized/borohydride-reduced modified heparin; human mesangial cell; high glucose; proliferation; cell cycle

Proliferation of intrinsic glomerular mesangial cells and subsequent development of mesangial matrix expansion are prominent features of glomerular disease. Diabetic nephropathy is also characterized by early mesangial cell proliferation, followed by accumulation of extracelluar matrix proteins. ${ }^{1,2)}$ Cell proliferation is ultimately a nuclear event and is divided into different phases in what is called the cell cycle. ${ }^{3)}$ Proliferation, hypertrophy, and apoptosis of renal injury are linked at the level of the cell cycle." In vivo, high glucose induces a limited proliferation ${ }^{5)}$ and hypertrophy, ${ }^{6}$ and cell cycle analysis revealed that glucose arrests cells in the $\mathrm{G}_{1}$ phase. ${ }^{7}$

Heparin is a polysulfated glycoaminoglycan that has been used as an anticoagulant for $>60$ years. ${ }^{8)}$ In addition to its anticoagulant activity, heparin has numerous biological activities such as anti-inflammatory and anti-metastatic activities. ${ }^{9}{ }^{10)}$ These activities are associated with the complicated structure of heparin. Heparin comprises alternating repeating disaccharide units of varying lengths with an amino sugar (either glucosamine or galactosamine) and uronic acid (either glucuronic or iduronic acid) residue. ${ }^{11)}$ Heparin has been used for the treatment of glomerulonephritis in several experimental and human glomerular diseases ${ }^{12-16)}$ including diabetic nephropathy. ${ }^{17)}$ Heparin can suppress the matrix expression of mesangial cells induced by high glucose in vitro. ${ }^{18)}$ However, its strong anticoagulant activity and potentiality of bleeding contraindicates its usage in this field. Many investigators have therefore undertaken to try to find heparin derivatives with low anticoagulant activity but preserving its ability for the treatment of glomerular diseases. It has been reported that some heparin derivatives (low molecular-weight heparin, ${ }^{19)} \mathrm{N}$-desulfated/acetylated heparin, ${ }^{20)}$ sulodexide ${ }^{21)}$ (low molecular-weight heparin and dermatan sulphate mixture) have beneficial effects on nephropathy.

Diabetic nephropathy is the leading cause of endstage renal disease, and is characterized by early proliferation and hypertrophy. Exposing murine mesangial cells to high glucose has a biphasic effect on growth, being pro-proliferation early at $24 \mathrm{~h}$ of incubation, but antiproliferative thereafter, leading to $G_{1}$ arrest. $G_{1}$ phase arrest is associated with cell hypertrophy. ${ }^{7)}$ A biphasic growth response of early proliferation and subsequent hypertrophy in mesangial cells was also observed in vivo in streptozotocin-induced diabetes mellitus. ${ }^{22)}$ Therefore, cell cycle alteration is intimately associated with diabetic nephropathy and cell cycle regulation may be used for development of future therapeutics. ${ }^{23)}$ Antioxidants, taurine and vitamin E, reversed the antiproliferative effect of high glucose in cultured mesangial cells. ${ }^{24)}$ Previous study has indicated that heparin does not have direct antioxidant activity. ${ }^{25}$ Whether chemically modified heparin has ability to inhibit high glucose-induced mesangial cell growth and its possible mechanism are still unknown.

A major point of concern in the long-term treatment of diabetic nephropathy with heparin is the risk of bleeding. ${ }^{27)}$ OR-heparin, a non-anticoagulation heparin derivate, provides a unique opportunity for treatment of diabetic nephropathy. In the present study, we investigated whether OR-heparin can inhibit mesangial cell proliferation induced by high glucose, and its influence on the cell cycle.

\section{MATERIALS AND METHODS}

Materials Unfractionated sodium heparin (YanTai Dongcheng Biochemicals Co., Ltd., China); APTT assay kits (Taiyang Biotechnology Co., Ltd., China); Propidium Iodide, PI (Sigma); BCA protein assay kit (Beyotime Institute of Biotechnology, China); anti-p2 $7^{\text {kip1 }}$, cyclin-dependent kinase 2 (CDK2), $\beta$-actin polyclonal antibody, and peroxidase-conjugated goat anti-rabbit Ig (Boster Biotech. China); Rabbit anti-phospho-ERK1/2(Thr202/Tyr204) (ZYMED); p44/p42 MAP kinase antibody (Cell signaling); ROS detection assay kit (Beyotime Institute of Biotechnology, China). All other chemical reagents are analytical grade or better. All cell-cultured reagents were obtained from Gibco-BRL.

An established stable human mesangial cell line (HMC) was used in experiments (kindly donated by Professor Ruan $\mathrm{XZ}$ ). Human mesangial cells were immortalized by transfec- 
tion with T-SV40 and H-ras oncogene, retaining many of the morphological and physiological features of normal HMCs. ${ }^{27,28)}$ HMCs were maintained in Dulbecco's modified Eagle's medium (DMEM) containing 10\% FCS, penicillin (100 U/ml), streptomycin $(100 \mu \mathrm{g} / \mathrm{ml})$, HEPES (15 mM), and glucose $(5 \mathrm{~mm})$ at $37^{\circ} \mathrm{C}$ in an atmosphere containing $5 \%$ $\mathrm{CO}_{2}-95 \%$ air. Cultures were passaged twice weekly at $1: 4$ split with the above-mentioned medium.

Preparation of OR-Heparin Deviates OR-heparin was prepared as previously described, ${ }^{29)} 1.3 \mathrm{~g}$ of heparin sodium salt was added to $50 \mathrm{ml}$ of a reaction solution containing $50 \mathrm{~mm}$ sodium periodate and $50 \mathrm{~mm}$ sodium acetate $(\mathrm{pH} 5.0)$ and the oxidation reaction was carried out at $4{ }^{\circ} \mathrm{C}$ for $3 \mathrm{~d}$. The reaction was terminated by addition of sufficient glycerol (final concentration, $250 \mathrm{~mm}$ ) to degrade the excess periodate. The reaction mixture was dialyzed to yield periodateoxidized heparin. The oxidized material was dissolved in $30 \mathrm{ml}$ of $0.2 \mathrm{M}$ sodium borohydride and allowed to stand at $4{ }^{\circ} \mathrm{C}$ for $3 \mathrm{~h}$, then adjusted to $\mathrm{pH} 5.0$ and allowed to stand at room temperature for $30 \mathrm{~min}$, resulting in the degradation again adjusted to $\mathrm{pH} 9.5$ with $5 \mathrm{~m} \mathrm{NaOH}$, dialyzed against distilled water for $2 \mathrm{~d}$, and lyophilized to yield of OR-heparin as the sodium salt.

NMR Analysis of OR-Heparin OR-Heparin was characterized by ${ }^{1} \mathrm{H}$ - and ${ }^{13} \mathrm{C}$-NMR spectroscopy. Deuterium-exchanged samples were dissolved in $\mathrm{D}_{2} \mathrm{O}$ and spectra recorded by Bruker AVANCE AV-500 spectrometer.

Activated Partial Thromboplastin Time (APTT) of OR-Heparin For APTT assay, citrated human plasma $(100 \mu \mathrm{l})$ was mixed with $100 \mu \mathrm{l}$ sample solution at $2 \mu \mathrm{g} / \mathrm{ml}$ and incubated for $1 \mathrm{~min}$ at $37^{\circ} \mathrm{C}$. Then, APTT assay reagent $(100 \mu \mathrm{l})$ was added to the mixture and incubated at $37^{\circ} \mathrm{C}$ for 6 min. $\mathrm{CaCl}_{2} 25 \mathrm{~mm}(100 \mu \mathrm{l})$ was added and the clotting time was recorded.

Antiproliferative Activity of OR-Heparin Cells were cultured in 96-well plates at densities of $10000 \mathrm{~cm}^{-2}$ in Dulbecco's modified Eagle's medium (DMEM) (5 mM glucose) supplemented with $10 \%$ FCS, until subconfluency was attained. Cell growth was arrested by lowering the FCS content of the medium to $0.5 \%$. After $24 \mathrm{~h}$, cells were then either left unstimulated or growth was initiated by DMEM containing either 5 or $25 \mathrm{~mm}$ glucose with $0.5 \%$ FCS in the presence or absence of OR-heparin solutions that were prepared fresh on the day of addition from a $10-\mathrm{mg} / \mathrm{ml}$ stock solution. The plates were then incubated for $24 \mathrm{~h}$. Proliferation was examined by MTT reduction assay.

Cell Cycle Analysis Cell cycle distribution was analyzed by flow cytometry using PI staining. Briefly, after synchronization with serum deprivation for $24 \mathrm{~h}$, cells were treated with LG ( $5 \mathrm{~mm}$ glucose) or HG ( $25 \mathrm{~mm}$ glucose) in the absence or presence of OR-heparin for $24 \mathrm{~h}$. Cells were harvested by trypsinization, washed with PBS, then fixed in $70 \%$ cold ethanol and stored at $4{ }^{\circ} \mathrm{C}$ for $12 \mathrm{~h}$. After removal of ethanol by centrifugation, the cells were incubated with PBS containing $50 \mu \mathrm{g} / \mathrm{ml}$ RNAase at $37^{\circ} \mathrm{C}$ for $30 \mathrm{~min}$, and stained with a solution containing $50 \mu \mathrm{g} / \mathrm{ml}$ PI for $30 \mathrm{~min}$ in the dark. Stained nuclei were analyzed for DNA-PI fluorescence by Becton Dickinson FACScan flow cytometer and the populations in $G_{1}, S$, and $G_{2}$ phases were determined by Modfit cell cycle analysis program (Verity Software House Inc.); cells were classified as being in $G_{1}, S$, or $G_{2}$ depending on the intensity of the fluorescence peaks.

Western Blotting Analysis Synchronized cells were divided into four groups: (A) LG (5 mM glucose); (B) LG+OR-heparin $(0.5 \mathrm{mg} / \mathrm{ml})$; (C) $\mathrm{HG}$ (25 mm glucose); (D) $\mathrm{HG}+\mathrm{OR}$-heparin $(0.5 \mathrm{mg} / \mathrm{ml})$. After culture for $24 \mathrm{~h}$, cell extracts were prepared with cold buffer A ( $50 \mathrm{~mm}$ Tris- $\mathrm{HCl}, \mathrm{pH}$ 7.5, $150 \mathrm{~mm} \mathrm{NaCl}, 20 \mathrm{~mm} \mathrm{NaF}, 1 \mathrm{~mm}$ EDTA, 6 mм EGTA, $15 \mathrm{~mm}$ sodium pyrophosphate, $30 \mathrm{~mm} p$-nitrophenyl phosphate, $1 \mathrm{~mm}$ benzamidine, $0.1 \mathrm{~mm}$ PMSF, 1\% Nonidet P-40) for $\mathrm{p} 27^{\mathrm{kip} 1}$, and CDK2, buffer B (20 mM HEPES, pH 8.0, $1 \mathrm{~mm} \mathrm{Na} \mathrm{VO}_{4}, 1 \mathrm{~mm}$ EGTA, $1 \mathrm{~mm}$ PMSF, $20 \mu \mathrm{M}$ leupeptin, $0.15 \mathrm{U} / \mathrm{ml}$ aprotinin, $0.1 \%$ Nonidet P-40) for ERK1/2. Extracts were centrifuged at $12000 \mathrm{rpm}$ at $4{ }^{\circ} \mathrm{C}$ for $10 \mathrm{~min}$. Equal amounts of protein were resolved by $12 \%\left(\mathrm{p} 27^{\mathrm{kip} 1}\right.$ and CDK2) or $10 \%$ (ERK1/2) SDS-PAGE and transferred to polyvinylidene difluoride membrane (Millipore). The resulting membranes were probed with anti-p2 $7^{\text {kip1 }}$, CDK2 polyclonal antibody, or anti-phospho-ERK1/2 (Thr202/Tyr204), or $\mathrm{p} 44 / \mathrm{p} 42$ MAP kinase antibody, incubated at $4{ }^{\circ} \mathrm{C}$ overnight, then incubated with horseradish peroxidase tagged goat anti-rabbit Ig polyclonal antibody, and developed with ECL system (Amersham Pharmacia Biotech).

Detection of Intracellular ROS Intracellular reactive oxygen species (ROS) were detected by oxidation-sensitive fluorescent probe (DCFH-DA). After treatment with high glucose in the absence or presence of OR-heparin for $24 \mathrm{~h}$, cells were washed twice in PBS. They were then incubated with $10 \mu \mathrm{mol} / 1 \mathrm{DCFH}-\mathrm{DA}$ at $37^{\circ} \mathrm{C}$ for $30 \mathrm{~min}$ according to the manufacturer's instruction. DCFH-DA was deacetylated intracellularly by nonspecific esterase, which was further oxidized by ROS to the fluorescent compound 2,7-dichlorofluorescein (DCF). DCF fluorescence was detected by FACScan flow cytometer (Becton Dickinson). For each sample 10000 events were collected.

Statistical Analysis Values are represented as mean士 S.D. Data were compared using one-way repeated measures analysis of variance (ANOVA), where appropriate, followed by Bonferroni's $t$-test to evaluated differences between treatment groups. Values with $p<0.05$ were considered significant.

\section{RESULTS}

Structure Confirmed and Anticoagulant Activity of OR-Heparin Using an established method, we produced OR-heparin by chemical modification. The structure of ORheparin was confirmed by NMR (Fig. 1); C (2)-C (3) bonds of the non-sulfated uronic acid (I) residues were cleaved, but this did not influence other groups of heparin.

To examine the anticoagulant activity of OR-heparin, we carried out APTT assay. At the concentrations of $2 \mu \mathrm{g} / \mathrm{ml}$, the APTT value for OR-heparin was dramatically reduced $(52.27 \pm 0.52, \quad n=3)$ compared with standard heparin $(143.52 \pm 1.79, n=3)$. We designated OR-heparin as a heparin derivative with low anticoagulation activity and applied it in the following experiments.

Antiproliferation Activity of OR-Heparin With high glucose $(25 \mathrm{~mm})$ stimulation for $24 \mathrm{~h}$, mesangial cells dramatically proliferated compared with in low glucose $(5 \mathrm{~mm})$ $(p<0.001)$. OR-heparin inhibited high glucose-induced mesangial cell proliferation with dose-dependent characteristic (Fig. 2). At a concentration of $1 \mathrm{mg} / \mathrm{ml}$, OR-heparin al- 


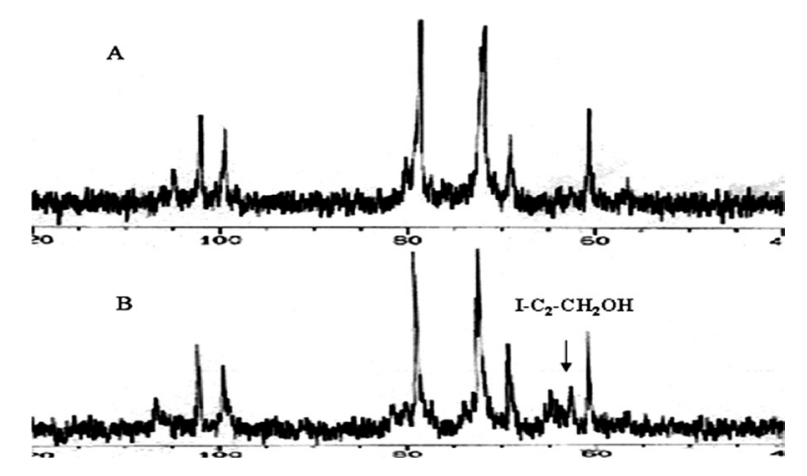

Fig. 1. ${ }^{13} \mathrm{C}-\mathrm{NMR}$ Spectrum of Heparin (A) and OR-Heparin (B)

$\mathrm{I}-\mathrm{C}_{2}-\mathrm{CH}_{2} \mathrm{OH}$, the $\mathrm{C}_{2}-\mathrm{C}_{3}$ bonds of uronic acid (I) of heparin are cleaved and form I$\mathrm{C}_{2}-\mathrm{CH}_{2} \mathrm{OH}$. Abbreviation; OR-heparin, periodate-oxidized/borohydride-reduced modified heparin.

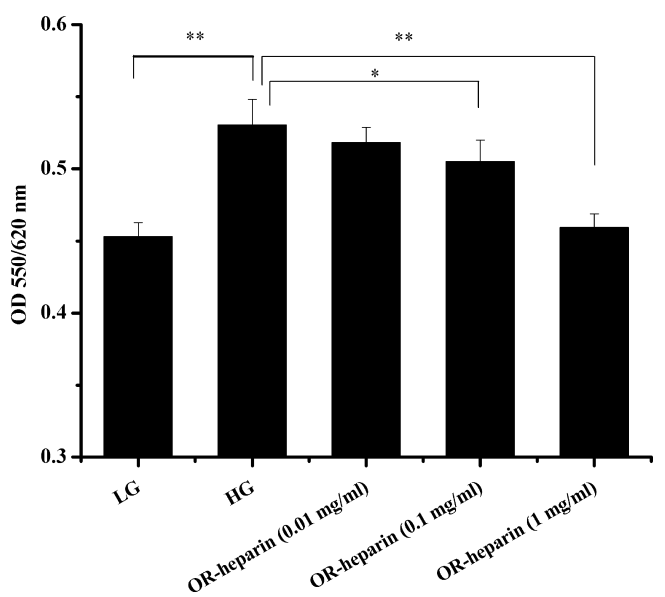

Fig. 2. Attenuation of High Glucose-Stimulated Proliferation of HMC by OR-Heparin

Synchronized cells were treated with LG ( $5 \mathrm{~mm}$ glucose) or HG ( $25 \mathrm{~mm}$ glucose) or $\mathrm{HG}+\mathrm{OR}$-heparin for $24 \mathrm{~h}$. Proliferation was examined by MTT reduction assay. Data are mean \pm S.D. of six independent experiments, $* p<0.01, * * p<0.001$. Abbreviations HMC, human mesangial cells; OR-heparin, periodate-oxidized/borohydride-reduced modified heparin; LG, low glucose (5 mm); HG, high glucose (25 mm).

most completely inhibited proliferation $(p<0.001) .5 \mathrm{mg} / \mathrm{ml}$ OR-heparin for $48 \mathrm{~h}$ did not influence the viability of mesangial cells as assessed by Trypan Blue exclusion ( $>95 \%$ ), indicating that OR-heparin at $5 \mathrm{mg} / \mathrm{ml}$ had no direct cytotoxicity.

High Glucose-Induced Cell Cycle Change and Influence of OR-Heparin Fluorescence-activated cell sorting (FACS) analysis was used to determine the effects of high glucose on the progression of mesangial cells through the cell cycle after $24 \mathrm{~h}$. Synchronized cells treated with $25 \mathrm{~mm}$ glucose for $24 \mathrm{~h}$ significantly increased the number of cells in the $G_{1}$ phase and decreased the number of cells in $S$ phase compared with $5 \mathrm{~mm}$ glucose treatment. OR-heparin dose-dependently increased the percentage of $\mathrm{S}$ phase, and downregulated the percentage of $\mathrm{G}_{1}$ phase (Fig. 3). With prolonged incubation for $48 \mathrm{~h}$, high glucose slightly increased the percentage of $\mathrm{G}_{1}$ phase cells compared with high glucose for $24 \mathrm{~h}$, but the difference was not significant $(p>0.05$, data not shown).

Western Blotting Assay p27 $7^{\mathrm{kip} 1}$ and CDK2 Expression with High Glucose Stimulate and Influence of OR-Heparin Mesangial cells cultured with $25 \mathrm{~mm}$ glucose for $24 \mathrm{~h}$ did not alter CDK2 expression, but p2 $7^{\mathrm{kip} 1}$ dramatically increased. OR-heparin had no significant effect on CDK2 and
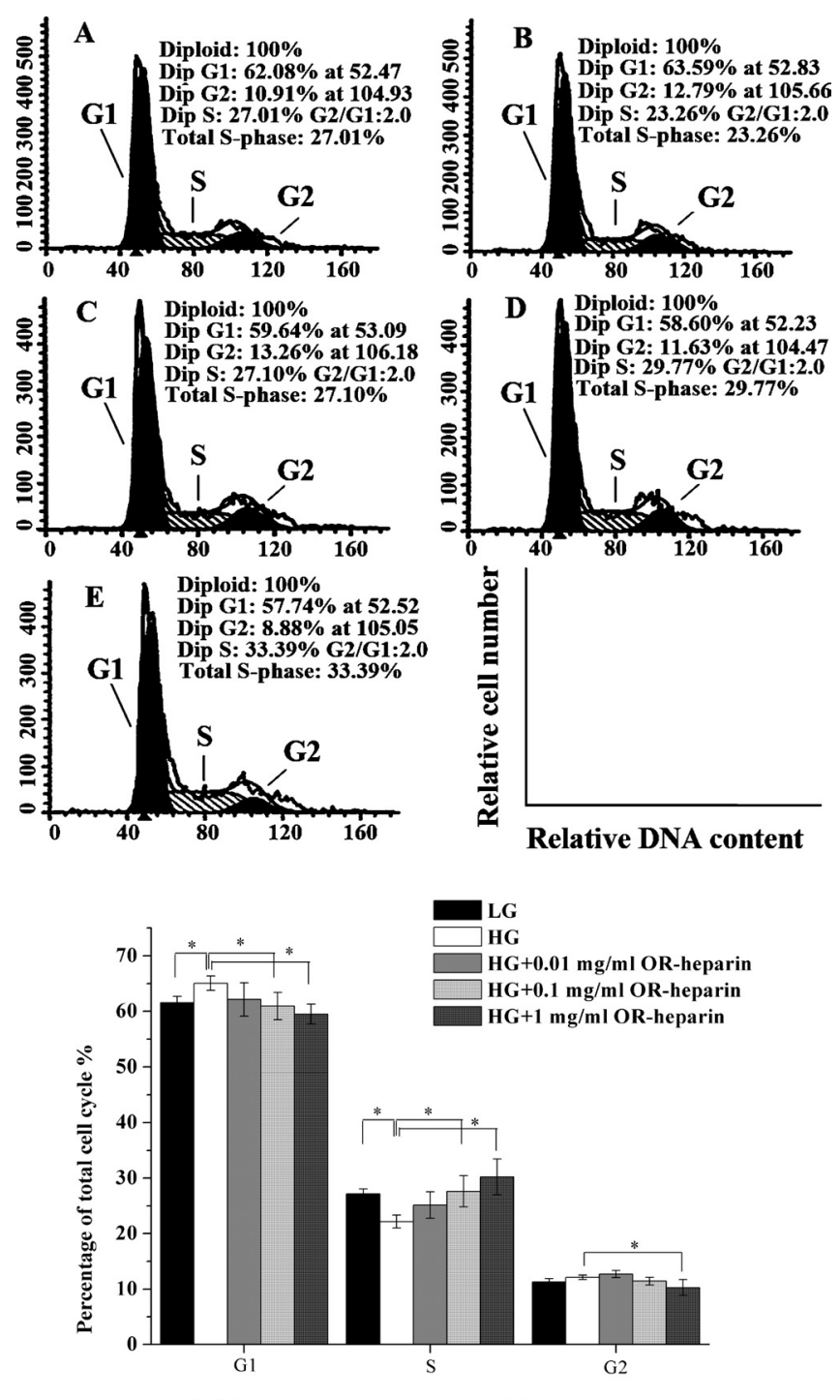

HMC cultured in high glucose for $24 \mathrm{~h}$ with OR-heparin

Fig. 3. High Glucose-Induced Cell Cycle Change and Influence of ORHeparin

Synchronized cells were treated with LG ( $5 \mathrm{~mm}$ glucose) or HG ( $25 \mathrm{~mm}$ glucose) or $\mathrm{HG}$ with OR-heparin for $24 \mathrm{~h}$; cellular DNA of these cells was stained with propidium iodide and assayed by flow cytometry. A. LG ( $5 \mathrm{~mm}$ glucose); B. HG ( $25 \mathrm{~mm}$ glucose); C. HG $+0.01 \mathrm{mg} / \mathrm{ml}$ OR-heparin; D. HG+ $0.1 \mathrm{mg} / \mathrm{ml}$ OR-heparin; E. HG+1 mg/ml ORheparin. The gray area represents $G_{1}$ (left) and $G_{2}$ (right) and hatched area represents the number of cells in $\mathrm{S}$ phase, as indicated on the upper panel. The lower panel is a bar graph of the average percentages of $\mathrm{G}_{1}, \mathrm{~S}$ and $\mathrm{G}_{2}$ phase of different groups. Results are based on cell from three individual experiments, $* p<0.05$. Abbreviations; OR-heparin, periodate-oxidized/borohydride-reduced modified heparin; LG, low glucose (5 mM); $\mathrm{HG}$, high glucose (25 mm).

$\mathrm{p} 27^{\mathrm{kip} 1}$ expression when cultured with low glucose. However, it inhibited high glucose-induced p2 $7^{\text {kip1 }}$ expression (Fig. 4).

High Glucose Activated ERK1/2 Phosphorylation and Influence of OR-Heparin Using phospho-specific antibodies, western blot analysis revealed that ERK1 and ERK2 were activated (phosphorylated) in mesangial cells after exposure to $25 \mathrm{~mm}$ glucose for $24 \mathrm{~h}$. Treatment with OR-heparin remarkably inhibited high glucose-activated ERK1 and ERK2 phosphorylation. On the other hand, OR-heparin did not influence ERK1 and ERK2 phosphorylation when cultured with $5 \mathrm{~mm}$ glucose. Total ERK1/2 was also examined with anti-ERK1/2, but no significant change was found compared with mesangial cells cultured with low glucose (Fig. 5). These data indicate that OR-heparin inhibits high glu- 

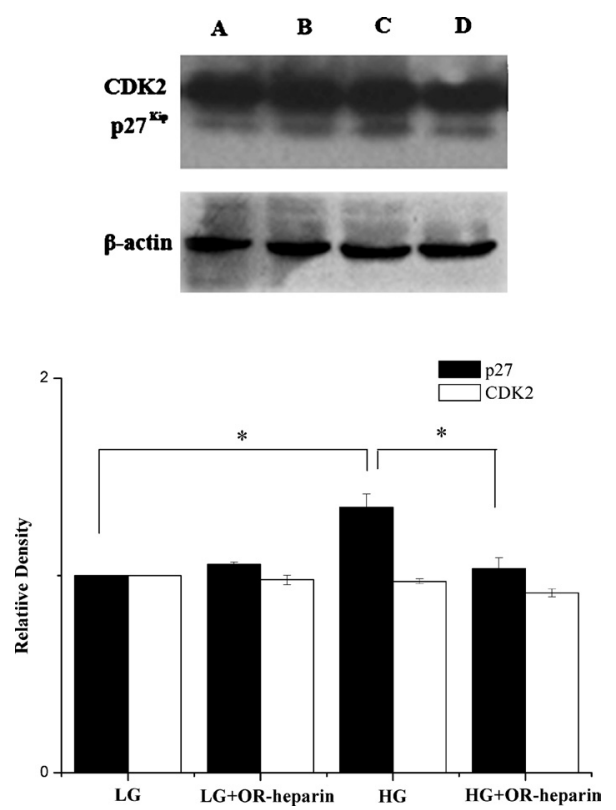

Fig. 4. Western Blotting Assay of CDK2 and $\mathrm{p} 27^{\mathrm{kip} 1}$ Expression $(n=3)$, $* p<0.01$

Synchronized cells were treated with A. LG (5 mm glucose), B. LG+OR-heparin $(0.5 \mathrm{mg} / \mathrm{ml})$, C. HG $(25 \mathrm{~mm}$ glucose $)$ or D. HG+OR-heparin $(0.5 \mathrm{mg} / \mathrm{ml})$ for $24 \mathrm{~h}$; equal amounts of protein extraction were resolved by $12 \%$ SDS-PAGE and transferred to polyvinylidene difluoride membrane, and probed with anti-p27 $7^{\mathrm{kip} 1}$, CDK2, or $\beta$-actin polyclonal antibody. Bands were displayed with secondary antibody and ECL system. Abbreviations; LG, low glucose (5 mM); HG, high glucose (25 mM); OR-heparin, periodate-oxidized/borohydride-reduced modified heparin.
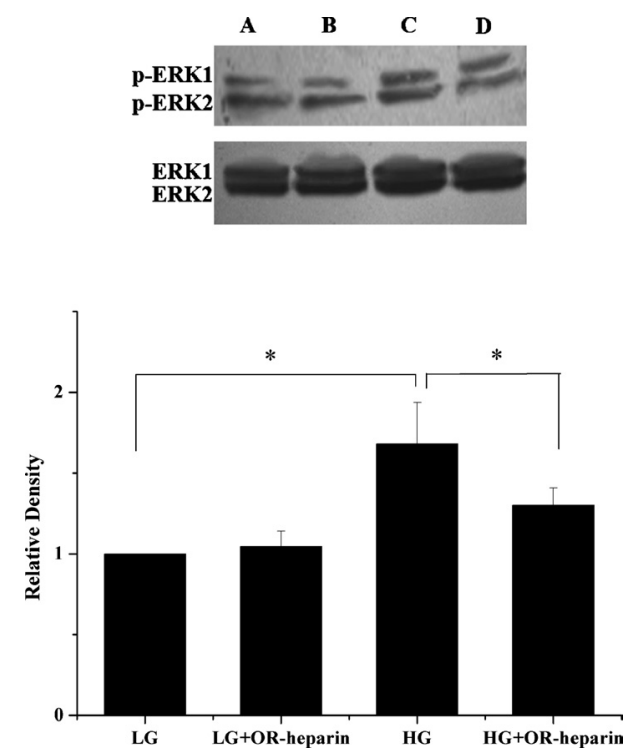

Fig. 5. Western Blotting Assay of p-ERK1/2 and ERK1/2 Expression $(n=3), * p<0.01$

Synchronized cells treated with A. LG ( $5 \mathrm{~mm}$ glucose), B. LG+OR-heparin $(0.5 \mathrm{mg} / \mathrm{ml})$, C. HG $(25 \mathrm{~mm}$ glucose $)$ or D. HG+OR-heparin $(0.5 \mathrm{mg} / \mathrm{ml})$ for $24 \mathrm{~h}$; equal amounts of protein extraction were resolved by $10 \%$ SDS-PAGE and transferred to polyvinylidene difluoride membrane, and probed with anti-phospho-ERK1/2 or p44/p42 MAP kinase antibody. Bands were displayed with secondary antibody and ECL system. Abbreviations; p-ERK1/2, phospho-ERK1/2; MAP kinase, mitogen-activated protein kinase; LG, low glucose $(5 \mathrm{~mm})$; HG, high glucose $(25 \mathrm{~mm})$; OR-heparin, periodate-oxidized/borohydride-reduced modified heparin.

cose-activated ERK1/2 phosphorylation without influencing total ERK1/2 expression.

Effects of High Glucose and OR-Heparin on ROS in Mesangial Cell Mesangial cells treated with $25 \mathrm{~mm}$ glu-

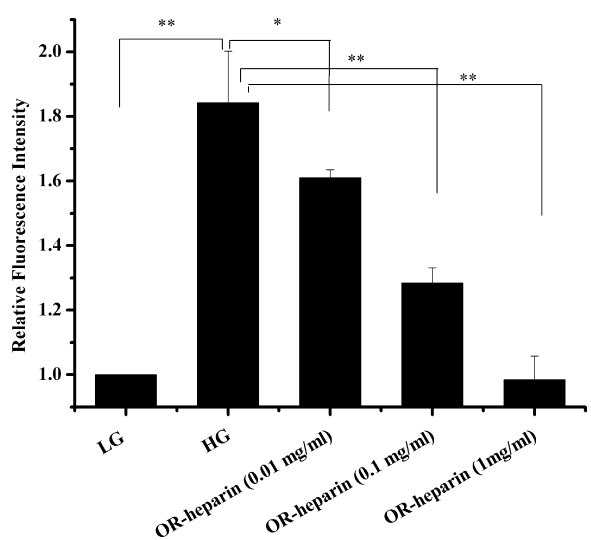

Fig. 6. Effects of High Glucose and OR-Heparin on Intracellular ROS in Mesangial Cells

Synchronized cells were treated with LG ( $5 \mathrm{~mm}$ glucose), or HG ( $25 \mathrm{~mm}$ glucose), or $\mathrm{HG}+\mathrm{OR}$-heparin for $24 \mathrm{~h}$. Intracellular ROS were detected by oxidation-sensitive fluorescent probe (DCFH-DA) with FACScan flow cytometer. Data are mean \pm S.D. of six independent experiments, $* p<0.01, * * p<0.001$. Abbreviations; OR-heparin, periodate-oxidized/borohydride-reduced modified heparin; ROS, reactive oxygen species; LG, low glucose (5 mM); HG, high glucose ( $25 \mathrm{~mm})$

cose for $24 \mathrm{~h}$ dramatically induced ROS generation compared with those cultured in $5 \mathrm{~mm}$ glucose $(p<0.001)$; OR-heparin suppressed ROS generation induced by high glucose in a dose-dependent manner (Fig. 6).

\section{DISCUSSION}

Control of cell division is a tightly regulated process involving a family of proteins termed cyclins and cyclin-dependent kinases (CDKs). Briefly, cyclins are proteins whose expression varies with the stage of cell cycle. They have a very short half-life ( $\mathrm{ca} .60 \mathrm{~min}$ ), and bind to constitutively expressed CDKs at pivotal points in the cycle. Cyclin-dependent kinase inhibitors (CDKIs) are activated by phosphorylation and inhibit cell-cycle progression by blocking CDK activity. Previous studies showed that specific CDKIs are required and essential for $\mathrm{G}_{1}$ arrest and hypertrophy induced by high glucose. Exposing mesangial cells to high glucose increases $\mathrm{p} 21^{\text {Cip }}$ and $\mathrm{p} 27^{\mathrm{kip} 1}$ protein expression but does not influence mRNA abundance. ${ }^{30,31)}$ High glucose increases oxygen radical formation by increasing mitochondrial oxygen consumption, which activates ERK1/2. Activated ERK1/2 phosphorylates $\mathrm{p} 27^{\mathrm{Kip} 1}$ on serine residue 178 . This reduces p27 degradation by decreasing binding to the ubiquitin-ligase complex. These events lead to $G_{1}$ phase arrest and concomitant hypertrophy. ${ }^{23)}$ Mesangial cells exposed to high glucose also rapidly induce expression of the immediate early response genes $c$-fos and $c$-jun, ${ }^{32)}$ which is an early indicator of quiescent cells into the cell cycle, that is followed by increased AP-1 binding activity and permits eventual progression to $\mathrm{S}$ phase and allows cell proliferation. After one or two complete of rounds of cell-cycle progression with completion of mitosis, cells are arrested in $\mathrm{G}_{1}$-phase and undergo hypertrophy. ${ }^{7)}$ Activation of ERK leads to induction of $c$-fos by phosphorylation of the transcription factor ELK-1. ${ }^{33)}$ Therefore we presume that activated ERK1/2 is critical for mesangial cell early proliferation and cell arrest on $\mathrm{G}_{1}$ phase under high glucose circumstance. Blocking the activation of ERK can account for the partial suppression of $c$-fos induction and can potentially account for inhibition of subsequent 
AP-1-dependent events including cell proliferation.

In the present study, we demonstrated that OR-heparin with low anticoagulation activity inhibits high glucose-induced early proliferation with dose-dependent characteristics and suppresses ROS accumulation. ROS activate ERK1/2, which phosphorylates $\mathrm{p} 27^{\mathrm{Kip} 1}$ on serine residue 178 . As mentioned above, activation of ERK also leads to induction of $c$ fos, which promotes AP-1 activity and initiates cell proliferation. We also found that OR-heparin blocks high glucose-activated ERK1/2 phosphorylation and inhibits p2 $7^{\mathrm{Kip} 1}$ expression. Therefore we presumed that OR-heparin inhibits high glucose-induced mesangial cell early proliferation through suppressing ROS accumulation and blocking ERK1/2 phosphorylation. The results of cell cycle analysis demonstrating that OR-heparin inhibits high glucose-induced proliferation is associated with an increase of the number of cells in $S$ phase of the cell cycle. This indicated that OR-heparin induces a delay in $\mathrm{S}$ phase progression after high glucose stimulated quiescent cells into the cell cycle.

There is no report on the influence of heparin on high glucose-induced cell cycle change in mesangial cells. We observed that heparin also has ability to inhibit high glucose-induced proliferation, compared with OR-heparin, although the inhibitory activity was not significantly different $(p>0.05$, data not shown). As for cell cycle, heparin also can release high glucose-arrested mesangial cells in $G_{1}$ phase and increase the number of cells in $\mathrm{S}$ phase in a dose-dependent manner. This indicates that OR-heparin has the same antiproliferative activity as heparin, but it significantly reduced anticoagulation activity.

Although a previous report states that heparin does not have indirect antioxidant activity, ${ }^{25)}$ whether OR-heparin reacts directly with ROS is still unknown. We investigated some antioxidant activity of OR-heparin and heparin, such as superoxide radical scavenging, hydroxyl radical scavenging, and total antioxidant activity in a linoleic acid system. Both OR-heparin and heparin did not display significant antioxidant activity (data not shown).

The mechanism of heparin suppression of high glucose-induced mesangial cell intracellular ROS is not fully understood. Some reports have shown that heparin induces the release of extracellular superoxide dismutase from endothelial cells, ${ }^{34)}$ and this may be the reason for heparin's protection from oxygen radical-mediated injury. ${ }^{35)}$ Those authors did not observe heparin-induced release of SOD from red blood cells, but the influence of heparin on erythrocytes was examined under in vitro conditions. They assumed that the increased activity of erythrocyte SOD was the result of displacement of the enzyme, anchored to the endothelial cells by heparin. ${ }^{34)}$ Whether OR-heparin has a similar mechanism on suppression of intracellular ROS needs further investigation.

In summary, OR-heparin effectively reduces its anticoagulant activity due to the unique antithrombin-binding pentasaccharide sequence of heparin being cleaved by chemical modification. OR-heparin has ability to release high glucoseinduced $G_{1}$ phase arrest and inhibits human mesangial cell proliferation through blocking ERK1/2 phosphorylation and delaying $\mathrm{S}$ phase progression, which may be correlated with
OR-heparin's suppressing ROS accumulation. All these results indicate that OR-heparin may have value as a therapeutic agent for diabetic nephropathy.

Acknowledgements This work was co-financed by the Teaching and Research Award Program for Outstanding Young Teachers (No. 2002383) and the National Natural Science Foundation (No. 30472061).

\section{REFERENCES}

1) Mahadevan P., Larkins R. G., Fraser J. R., Dunlop M. E., Diabetes, 45, 44-50 (1996).

2) Young B. A., Johnson R. L., Alpers C. E., Eng E., Gordon K., Floege J., Couser W. G., Kidney Int., 47, 935-944 (1995).

3) Norbury C., Nurse P., Annu. Rev. Biochem., 61, 441-471 (1992).

4) Shankland S. J., Kidney Int., 52, 294-308 (1997).

5) Cosio F. G., J. Am. Soc. Nephrol., 5, 1600-1609 (1995).

6) Sharma K., Jin Y., Guo J., Ziyadeh F. N., Diabetes, 45, 522-530 (1996).

7) Wolf G., Sharma K., Chen Y., Ericksen M., Ziyadeh F. N., Kidney Int., 42, 647-656(1992).

8) Mulligan J., Circulation, 19, 75-78 (1959).

9) Carri J., Thromb. Res., 16, 507-516 (1979).

10) Lever R., Page C. P., Nat. Rev. Drug Discov., 1, 140-180 (2002).

11) Tyrrell D. J., Horne A. P., Holme K. R., Preuss J. M., Page C. P., Adv Pharm., 46, 151-208 (1999).

12) Johnson R. J., Raines E. W., Floege J., Yoshimura A., Rrttzl P., Alpers C., Ross R., J. Exp. Med., 175, 1413-1416 (1992).

13) Floege J., Eng E., Young B. A., Couser W. G., Johnson R. I., Kidney Int., 43, 369-380 (1993).

14) Olson J. L., Kidney Int., 25, 376-382 (1984).

15) Striker L. J., Peten E. P., Elliot S. J., Doi T., Striker G. E., Lab. Invest., 164, 446-456 (1991).

16) Wardle E. N., Nephron, 73, 515-519 (1996).

17) Marshall S. M., Hansen K. W., Osterby R., Frystyk J., Orskov H., Flyvbjerg A., Am. J. Physiol., 271, 326-332 (1996).

18) Caenazzo C., Garbisa S., Onisto M., Zampieri M., Baggio B., Gambaro G., Nephrol. Dial. Transplant., 12, 443-448 (1997).

19) Tamsma J. T., Van der Woude F. J., Lemkes H. H. P. J., Nephrol. Dial. Transplant., 11, 182-185 (1996).

20) Purkerson M. L., Tollefsen D. M., Klahr S., J. Clin. Invest., 81, 69-74 (1988).

21) Gambaro G., Kinalska I., Oksa A., Pont'uch P., Hertlova M., Olsovsky J., Manitius J., Fedele D., Czekalski S., Perusicova J., Skrha J., Taton J., Grzeszczak W., Crepaldi G., J. Am. Soc. Nephrol., 13, 1615-1625 (2002).

22) Huang H. C., Preisig P. A., Kidney Int., 58, 162-172 (2000).

23) Wolf G., Shankland S. J., Prog. Cell Cycle Res., 5, 71-79 (2003).

24) Trachtman H., Futterweit S., Prenner J., Hanon S., Biochem. Biophys. Res. Commun., 199, 346-352 (1994).

25) Lapenna D., Mezzetti A., de Gioia S., Ciofani G., Marzio L., Di Ilio C., Cuccurullo F., Biochem. Pharmacol., 44, 188-191 (1992).

26) Gambaro G., Skrha J., Ceriello A., Diabetologia, 41, 975-979 (1998).

27) Ruan X. Z., Varghese Z., Powis S. H., Moorhead J. F., Kidney Int., 60, 1716 - 1725 (2001)

28) Sraer J. D., Delarue F., Hagege J., Feunteun J., Pinet F., Nguyen G., Rondeau E., Kidney Int., 49, 267-270 (1996).

29) Seigo U., Yutaka K., Harald R., Masayuki I., Takashi S., Hiroyuki M., Mamoru K., J. Biochem. (Tokyo), 133, 783 -789 (2003).

30) Wolf G., Ziyadeh F. N., Kidney Int., 56, 393- 405 (1999).

31) Kuan C. J., Al-Douahji M., Shankland S. J., J. Am. Soc. Nephrol., 9, 986-993 (1998).

32) Kreisberg J. I., Radnik R. A., Ayo S. H., Garoni J., Saikumar P., Kidney Int., 46, 105-112 (1994)

33) Rosen L. B., Ginty D. D., Greenberg M. E., Adv. Second. Messenger Phosphoprotein Res., 30, 225-253 (1995).

34) Karlsson K., Marklund S. L., Biochem. J., 242, 55-59 (1987).

35) Hiebert L. M., Liu J. M., Atherosclerosis, 83, 47-51 (1990). 